Proceedings of the 2018 International Scientific Conference 'Economic Sciences for Agribusiness and Rural Economy' No 2, Warsaw, 7-8 June 2018, pp. 180-187

\title{
DELIVERING CONSUMER VALUES BY CONSUMER FOOD COOPERATIVES - A CASE OF TWO TYPES OF COOPS FROM POLAND
}

\author{
Kiryll Zahkarov, Msc'; Mariusz Maciejczak, $\mathrm{PhD}^{2}$ \\ ${ }^{1}$ Faculty of Economics, Sumy National Agrarian University \\ ${ }^{2}$ Faculty of Economic Sciences, Warsaw University of Life Sciences - SGGW
}

\begin{abstract}
Consumer choice of a particular type of retail outlet greatly depends on the consumer values that the outlet provides. The aim of this research was to address specific consumer values created by consumer food cooperatives in general, and in addition to examine the difference in the consumer values provided by two major types of such coops in Poland. It is argued that consumer food cooperatives provide customers with unique blend of values, different from those of consumer cooperatives in general due to their close bond with agriculture and environment. Such coops could deliver their customers not only economic or hedonic values but also an additional environmental ones. The environmental values are prevailing in participatory type of coop, while the supermarket type can deliver better the economic values.
\end{abstract}

Keywords: consumer food cooperative, utilitarian values, hedonic values, environmental values, participatory cooperative, supermarket cooperative, Poland JEL codes: P13, Q13

\section{INTRODUCTION}

Historically, motivation for members and nonmembers to buy from consumer food cooperatives (CFCs) is changing together with emergence and development of the global food network, and the extent to which these coops provide specific values (Maciejczak, 2014). Before the emergence of global food market, the so called utilitarian values, that are economical and functional values, were the most important for customers. Today the hedonic values i.e. emotional, symbolic, social, epistemic, conditional or environmental seem to prevail (Finch, Trombley and Rabas, 1998).

The combination of customer values is dynamic and constantly changing in overall customer motivation. In recent decades the non-economic values are gaining more popularity and importance. However, the CFCs driven solely by non-economic values showed lesser vitality (Stephenson, 1963; Gliekman, 1977; Bilewicz and Spiewak, 2016).

A number of a consumer cooperative definitions can be found in the scholarly works. For example, Mikami (2010) defines a consumer cooperative simply

${ }^{1}$ Corresponding author: Herasym Kondratiev 160, Sumy, Ukraine, kyrillz@gmail.com, +380095 6158471

${ }^{2}$ Corresponding author: Nowoursynowska 166,02-787 Warsaw, Poland, mariusz_maciejczak@sggw.pl, +4822 5934235 
as 'a firm in which ownership to the firm is given to the customers of the firm'. Additionally, O'Sullivan and Sheffrin (2003) give a wider definition, for them: 'a consumer cooperative is a cooperative business owned by its customers for their mutual benefit. It is a form of free enterprise that is oriented toward service rather than pecuniary profit'. Yet there was very little attempt paid to the characteristic and definition of such economic entity as a consumer food cooperative. Zakharov and Maciejczak (2018) define modern CFC as a voluntarily organisation, aimed at eliminating middleman and buying quality food and related items directly from producers. The main task of a consumer food cooperative is to supply quality food or related items to the customers at the lowest price possible, while supporting local farmers with fair pay for their produce.

In Poland CFCs do not enjoy such diversity of organisational forms as those in other countries as the USA, for example. However, two distinct types of CFCs are now firmly established in the country: participatory cooperative and supermarket cooperative. Present Polish cooperatives are incorporating for their current needs the existing models that were developed in Europe and the USA. The first documented CFCs appeared in Fenwick, UK, in 1769 (Fairbairn, 1959), soon other CFCs got established in the country (Webb, 1930). The first CFCs, according to other scholars, were founded in Rochdale, UK (Greenberg and Watts, 2009), in 1844 (Fairbairn, 1959). Those first CFCs were solely of supermarket cooperative type. In the USA first cooperatives were established in the beginning of 20th century, and by 1960s a 'new wave' or participatory cooperatives emerged (Streed, Cliquet and Kagan, 2017). While supermarket cooperatives are based on the 'Rochdale model' and are aimed mostly at reducing costs of food (Thompson, 1994), participatory cooperatives are based not only on the 'Rochdale model' but also on the latest left-wing and environmentalist movements and tendencies (Hoyt, 1995).

There are certain differences in how North American and Western European scholars address the issue of CFCs. North American researchers focus on the competitive capacity of the CFCs, on their capitalisation, internal cooperation, and ability to create an egalitarian and sustainable local food network (Kloppenburg et al., 1996; Buttel, 1997; Allen et al., 1999; Mancino and Parliament, 2001). At the same time European researchers focus on the food safety and organic food certification, rural development and agricultural policy, especially when it comes to Common Agricultural Policy reform (Lowe, Buller and Ward, 2001; Grey, 2000; Goodman, 2003). British researchers are also focusing on the role of food distribution chains in sustainable development and sustainable consumption (Evans, 2011; Davies, 2014).

This difference comes from the fact, that the US CFCs are mostly for-profit ones, therefore issues of capitalisation and market competitiveness are among fist priorities for them, while European CFCs are mostly small non-profit entities. Europe has a larger number of the small family farms, thus 'farmer-city customer' relations are among priorities for the European scholars. Topics, that are of equal interest for both American and European scholars are those of embeddedness, urban agriculture development, localism and social relations in terms of food consumption (Jarosz, 2000; Sage, 2003).

First documented CFCs in Poland appeared in 1930 (Chyra-Rolicz, 1985, 1992), but after the WWII this cooperatives seized to exist, or were incorporated into more formalised soviet type consumer cooperatives. CFCs made their comeback in Poland in early 2010. Initially there were about 30 attempts to establish such cooperatives (Bilewicz, 2017). Those the very first CFCs established in Poland around 2010 were more focused on eliminating middleman from food supply chain, although in the following years they became more focused on supplying quality food to its members, or as Sage (2003) called it 'a good food'. By 2018 about half of the 'new wave' coops, established in 2010 still operate in Poland's food market, though holding an insignificantly small share of the food market. Those CFCs were initially entirely based on the participatory cooperatives model. However, later one of the cooperatives - 'Dobrze', has changed to a supermarket coop model and is successfully operating and consistently growing now. Another purely 'ideological', extremely socially-wing coop ('Warszawska'), after it's membership 
dropped to mere 17 members in 2017, decided to follow the suit and adjust their structure to that 'supermarket' model too. Detailed overview of the CFCs movement in Poland has been described by Maciejczak and Zakharov (2018). They stressed that due to the voluntary character based on networking activities they are subject to adjustment processes, which under the umbrella of the democratic governance, are focused on adaptive actions.

Thus, it can be observed that modern CFCs around the world are based on the contrary driving forces of pragmatism and idealism, which differently impact each particular cooperative and are changing over the time. While pragmatic drivers were more important for the first CFCs, and for those organised in 1930 1960, the idealistic drivers and food safety concerns are becoming the main drivers for the modern CFCs members (Sage, 2003; Bos and Owen, 2016; Streed, Cliquet and Kagan, 2017). Some scholars compare egoistic versus altruistic member motivation for joining CFCs (Birch, 2018), on the contrary the others call it idealistic versus pragmatic or hedonic values (Streed ,Cliquet and Kagan, 2017).

The basic research problem is, however, to find out which values drive the consumers to join on different level - as a member or non-member, the modern CFCs in Poland, and if these values depend on the type of such cooperative.

\section{MATERIALS AND METHODS}

The purpose of this paper is to identify specific set of values of CFCs that are the driving factors for consumers, forcing them to join such cooperatives or to buy from them. Based on the literature review the values has been identified. In order to verify to which extend the diagnosed values are provided, two CFCs from Warsaw, namely 'Dobrze' and 'Grochowska', were visited and participant observations have been performed. It was assumed that the participant observation combines participation in the operation of the organization being studied with maintenance of a professional distance that allows adequate observation and recording of data. Participant observation underscores the person's role as participant in the social setting that is observed
(Holloway, 1997). The CFCs selected for the case study have been chosen due to three reasons. Firstly, they were selected because of their proven vitality (both co-ops have been successfully operating since 2010 without any set-backs), secondly due to their dynamic development ('Dobrze' has grown from two founders in 2010 to almost 400 members in the beginning of 2018 and it has opened two new shops over that period of time; while 'Grochowska' has grown from 1 founder in 2010 to 700 members in the beginning of 2015 and it later split into several daughter co-ops, with 'Grochowska' remaining a mother-cooperative), and finally as per the diversification of their activities ('Grochowska' takes part in a re-socialisation project as well as in Community Supported Agriculture (CSA) Study Visits project and it organised a food sharing hub in Warsaw, while 'Dobrze' takes part in sociological research project and organises lectures on CFC and CSA. Both coops are now actively involved in the creation and maintenance of the CSAs).

\section{RESULTS AND DISCUSSION}

\section{Identifying customer values provided by CFCs}

Based on the literature review the values the CFCs provide for their consumers have been identified. The commonly used conceptual definition of a consumer value was given by Hollbrook (1999) and it stresses out that the value is relativistic, interactive, preferential, and experiential. Vargo and Lusch (2007) are also emphasizing subjectiveness of a customer value, stating that the value is 'determined by the beneficiary'. Based on the reviewed scholarly works it can be stated that presently there are three main approaches to the customer values definition: utilitarian, hedonic and multi-dimentional. For example, Babin, Darden and Griffin (1994) and Holbrook (1999) note that the utilitarian approach sees a customer as a problemsolver, driven by rationality, and is focused on taskrelated characteristics. On the other hand the hedonic approach is focused on the purchase and consumption process itself. It emphasizes the value of the shopping process itself as an emotional, social and entertainment activity. The presented research is built mostly on the theoretical background, developed by 
Finch, Trombley and Rabas (1998) and Talonen et al. (2016) who research and present customer values as a combination of utilitarian and hedonic values, and apply their conceptual framework to the consumer cooperatives in particular.

Due to the specific nature of Polish CFCs, and first of all, their non-profit nature, the values that they provide to it's customers would be somewhat different from those of a commercial enterprise. According to (Talonen et al., 2016) consumer cooperative creates following two groups of values coming from their customer ownership nature. The first one covers utilitarian values: economic value and functional value. The second one is hedonic values: emotional and experiential value and symbolic and social value. Finch, Trombley and Rabas (1998) also defines two more values of consumer cooperatives: epistemic values and conditional values. As CFCs are closely linked to natural environment preservation for they help to minimise negative social, environmental, economic and health impacts of global food distribution network (Feenstra, 1997; Seyfang, 2006; Williams et al., 2012; Sumner, McMurtry and Renglich, 2014). Natural environment preservation can be added as an additional value that could be connected to public goods (Maciejczak, 2009), to the values suggested by Talonen and Finch. The classification of customer values is presented in Table 1 .

Even though the consumer values of consumer cooperatives in general have been addressed by scholars in recent years (Feenstra, 1997; Finch, Trombley and Rabas, 1998; Talonen et al., 2016), previous discussion has not addressed CFCs as such. Moreover, due to the close connection of consumer cooperatives with agriculture, specifically with sustainable agricultural techniques (Sage,

Table 1. Classification of customer values, produced by modern consumer food cooperatives

\begin{tabular}{|c|c|}
\hline Values & Descriptions \\
\hline \multicolumn{2}{|r|}{ Utilitarian values } \\
\hline Economic value & $\begin{array}{l}\text { Monetary savings, value for money, best trade-off between price and overall benefits (Talonen } \\
\text { et al., 2016). }\end{array}$ \\
\hline Functional value & $\begin{array}{l}\text { Quality, convenience, finding the right product at the right time and place (Finch, Trombley } \\
\text { and Rabas, 1998; Talonen et al., 2016). }\end{array}$ \\
\hline \multicolumn{2}{|r|}{ Hedonic values } \\
\hline $\begin{array}{l}\text { Emotional and } \\
\text { Experiential value }\end{array}$ & $\begin{array}{l}\text { Exploration, entertainment, aesthetics, playfulness, escapism and enjoyment, pleasure and } \\
\text { emotional experience of the consumption process itself (Finch, Trombley and Rabas, 1998; } \\
\text { Talonen et al., 2016). }\end{array}$ \\
\hline Symbolic and social value & $\begin{array}{l}\text { Status and self-esteem, social value, self-expression (Finch, Trombley and Rabas, 1998; Talo- } \\
\text { nen et al., 2016). }\end{array}$ \\
\hline Epistemic value & $\begin{array}{l}\text { The ability to arouse curiosity, provide novelty or satisfy one's desire for knowledge (Finch, } \\
\text { Trombley and Rabas, 1998). }\end{array}$ \\
\hline Conditional value & $\begin{array}{l}\text { The ability to provide alternative choice, depending on situation and set of circumstances } \\
\text { faced by the customer (Finch, Trombley and Rabas, 1998). }\end{array}$ \\
\hline \multicolumn{2}{|r|}{ Environmental value } \\
\hline Public values & $\begin{array}{l}\text { The ability to provide customer with external benefits, such as cleaner environment (Maciej- } \\
\text { czak, 2009), the ability to take part in environment preservation and support of traditional } \\
\text { heritage of the regions by supporting farmers who practice environment-friendly or traditional } \\
\text { production techniques (own elaboration). }\end{array}$ \\
\hline
\end{tabular}

Source: own elaboration based on: Finch, Trombley and Rabas (1998); Maciejczak (2009), Talonen et al. (2016). 
2003), CFCs deliver its customers additional value, namely environmental value, that can be classified as both economical value due to external benefits that it creates (Maciejczak and Zakharov, 2011) and the hedonic value because of the satisfaction that it gives to CFCs customers by their participation in natural environment and traditional culture preservation (Bilewicz and Spiewak, 2016).

\section{The ability of CFCs to provide customer values - the comparison of two coops of different type from Warsaw}

It should be pointed out that different types of the CFCs can produce different blend of consumer values. Two types of the CFCs has been compared - supermarket type CFC 'Dobrze' and participatory type CFC 'Grochowska', both located in the capital city of Warsaw. CFC 'Dobrze' not only supplies food but operates a shop for both members and non-members, where salaried shop assistances and other staff serve customers and therefore are selling their labour for the monetary reward. This is the only partially commercialised cooperative, they follow all internationally accepted cooperative principles (Hoyt, 1996) equally, putting special stress on education. The CFC 'Grochowska' primarily is a food cooperative that is growing into some sort of multi-functional community cooperative, encouraging its members to mutually supply all sorts of services, such as car sharing, tool sharing, language lessons and other sorts of mutual help or exchange of goods and services. This is the only cooperative that doesn't follow the first principle of voluntary and open membership - the membership is voluntary, but not open - new members have to be approved by the management. The most important principle for them is concern for community, the second most important principle is education. As for the rest - they are equally important.

Both coops showed rather poor performance in terms of economic value as their prices are not much different from those of conventional supermarkets, while in terms of symbolic and social, epistemic and conditional values both types of the cooperatives showed very good performance, as well as in terms of emotional and experiential value - however, this value is delivered to a lesser degree in case of non- member customers of the supermarket CFC 'Dobrze', as they are not involved in voluntary work. In terms of functional value, the CFC 'Dobrze' has shown undoubtedly better performance thanks to the presence of actual shops with regular opening hours, while the CFC 'Grochowska' only provides its customers with a collection point opened one day a week. In terms of environmental value 'Grochowska' showed better performance as it distributes wider range of agricultural products, thus supporting larger number of organic or traditional farms. The ability of the researched two CFCs from Warsaw to provide the customer values discussed here, are presented in Table 2.

\section{CONCLUSIONS}

The consumer food cooperatives provide an alternative source of food purchase compared to mainstreamed large scale networks driven by super or hypermarkets. The ability of such alternative networks to develop depends on the extent to which they provide values to both their members and their consumers. It is argued that the researched CFCs can provide their customers with their own specific blend of values, different from those of consumer cooperatives in general. Through the fact that the consumers of the researched cooperatives are more closely attached to sustainable agricultural production, these CFCs could deliver their customers also additional value. This value can be described as an environmental value. It can be classified as both an economic and also as a hedonic value. It was found that the environmental values are prevailing in participatory type of coop, while the supermarket type can deliver better the economic values.

Against the background of the limited existing literature on the topic, this paper contributes to the studies on the drivers of development of CFCs, and explores the present basis of their functioning. It is undoubted, that the both selected coops can give their customers an enhanced scope of values, compared to that of the conventional supermarkets in Poland. Therefore the further research is needed in order to verify the scope to which the values contribute to CFCs consumers' satisfaction. 
Table 2. The ability to provide consumer values by CFC 'Grochowska' and CFC 'Dobrze'

\begin{tabular}{|c|c|}
\hline Supermarket type coop - CFC 'Dobrze' & Participatory type coop - CFC 'Grochowska' \\
\hline \multicolumn{2}{|l|}{ Economic value } \\
\hline $\begin{array}{l}\text { The agricultural produce prices are similar to those in super- } \\
\text { markets or just slightly lover, however prices for non-mem- } \\
\text { bers are normally higher than in supermarkets. }\end{array}$ & $\begin{array}{l}\text { The agricultural produce prices are similar to those in su- } \\
\text { permarkets or just slightly lover comparing to those in su- } \\
\text { permarkets. }\end{array}$ \\
\hline \multicolumn{2}{|c|}{ Functional value } \\
\hline $\begin{array}{l}\text { The presence of the actual shops, located in the city centre } \\
\text { and usual opening hours, as well as experienced staff make } \\
\text { functional value of the coop similar to that of usual super- } \\
\text { market, however lover number of customers makes purcha- } \\
\text { sing process quicker that gives this type of the coop in Po- } \\
\text { land certain advantage. }\end{array}$ & $\begin{array}{l}\text { The absence of the actual shops, and ability to make pur- } \\
\text { chases only once a week gives this type of the coop strong } \\
\text { disadvantage, however the coop can provide it's customers } \\
\text { with wider selection of products, as it is not limited by shop's } \\
\text { floor space. }\end{array}$ \\
\hline \multicolumn{2}{|c|}{ Emotional and experiential value } \\
\hline $\begin{array}{l}\text { The necessity of volunteer job provide wealth of emotional } \\
\text { and experimental value to members and some degree to it's } \\
\text { non-member customers. }\end{array}$ & $\begin{array}{l}\text { The necessity of volunteer job provides wealth of emotional } \\
\text { and experimental value. }\end{array}$ \\
\hline \multicolumn{2}{|c|}{ Symbolic and social value } \\
\hline $\begin{array}{l}\text { The coop provides symbolic and social value to both mem- } \\
\text { bers and non-members to a full degree. }\end{array}$ & $\begin{array}{l}\text { The coop provides symbolic and social value to a full de- } \\
\text { gree. }\end{array}$ \\
\hline \multicolumn{2}{|c|}{ Epistemic value } \\
\hline $\begin{array}{l}\text { The coop provides epistemic value to both members and } \\
\text { non-members to a full degree. }\end{array}$ & The coop provides epistemic value to a full degree. \\
\hline \multicolumn{2}{|c|}{ Conditional value } \\
\hline $\begin{array}{l}\text { The coop provides conditional value to both members and } \\
\text { non-members to a full degree. }\end{array}$ & The coop provides conditional value to a full degree. \\
\hline \multicolumn{2}{|c|}{ Environmental value } \\
\hline $\begin{array}{l}\text { The coop's policy of buying only 'ecological' or traditional- } \\
\text { ly grown produce generates certain environmental value. }\end{array}$ & $\begin{array}{l}\text { The coop's policy of buying only 'ecological' or traditionally } \\
\text { grown produce generates certain environmental value. The } \\
\text { coop claims to supply wider variety of products, involving } \\
\text { bigger number of the 'good food' suppliers, thus delivering } \\
\text { better environmental value. }\end{array}$ \\
\hline
\end{tabular}

Source: own elaboration.

\section{Acknowledgements}

This paper was developed in the framework of the Visegrad Scholarship Program under the scholarship 51700144 entitled 'Building the capitalization models of food consumer cooperatives in Poland and Ukraine based on best Polish, North American and Western European practices'. The support of the International Visegrad Fund is acknowledged.

\section{REFERENCES}

1. Allen, P., Fitzsimmons, M., Goodman, M., Warner, K. (2003). Shifting plates in the agrifood landscape: the tectonics of alternative agrifood initiatives in California. Journal of Rural Studies, 19, pp. 61-75.

2. Babin, B., Darden, W., Griffin, M. (1994). Work and/or fun: measuring hedonic and utilitarian shopping value. Journal of Consumer Research, 20 (4), pp. 644-656. 
3. Bilewicz, A., Spiewak, R. (2016). Enclaves of activism and taste: Consumer cooperatives in Poland as alternative food networks. Socio.hu. Social Science Review. Hungarian Academy of Sciences, Budapest.

4. Birch, D., Memery, J., De Silva Kanakaratne, M. (2018). The mindful consumer: Balancing egoistic and altruistic motivations to purchase local food. Journal of Retailing and Consumer Services, 40(C), pp. 221-228.

5. Bos, E., Owen, L. (2016). Virtual reconnection: The online spaces of alternative food networks in England. Journal of Rural Studies, 45, pp. 1-14.

6. Buttel, F. (1997). Some observations on agro-food change and the future of agricultural sustainability movements. In: Goodman, D., Watts, M.J. (eds.) Globalizing Food: Agrarian Questions and Global Restructuring. Routledge, London, pp. 344-365.

7. Chyra-Rolicz, Z. (1985). Pod spółdzielczym sztandarem. Historia polskiej spółdzielczości do 1982 r. [Under the cooperative banner. The history of Polish cooperative movement until 1982]. Wydawnictwo Spółdzielcze, Warszawa.

8. Chyra-Rolicz, Z. (1992). Z tradycji polskiej współdzielczości w II Rzeczypospolitej [From the tradition of Polish co-existence in the Second Polish Republic]. Wydawnictwo Spółdzielcze, Warszawa-Poznań.

9. Davies, A. (2014). Co-creating sustainable eating futures: Technology, ICT and citizen-consumer ambivalence. Department of Geography, Trinity College, Dublin.

10. Evans, D. (2011). Consuming conventions: sustainable consumption, ecological citizenship and the worlds of worth. Sociology and the Sustainable Consumption Institute. University of Manchester, Manchester.

11. Fairbairn, B. (1959). Meaning of Rochdale: The Rochdale pioneers and the co-operative principles. Centre for the Study of Co-operatives, University of Saskatchewan, Saskatoon.

12. Feenstra, G.W. (1997). Local food systems and sustainable communities. American Journal of Alternative Agriculture, 12 (1), pp. 28-36.

13. Finch, J., Trombley, C., Rabas, B. (1998). The role of multiple consumption values in food consumer cooperative patronage: An application of the theory of market choice behaviour. Journal or Marketing Management, 8 (1), pp. 44-56.

14. Gliekman, M. (1977). Proudly independent. The Environmental Magazine, May/June.

15. Goodman, D. (2003). The quality 'turn' and alternative food practices: reflections and agenda. (Editorial). Journal of Rural Studies, 19, pp. 1-7.

16. Greenberg, B., Watts, L. (2009). Social history of the United States. Vol 1. ABC-CLIO, Pennsylvania.
17. Grey, M. (2000). The industrial food stream and its alternatives in the United States: an introduction. Human Organization, 2, pp. 143-150.

18. Holbrook, M. (1999). Consumer value: A framework for analysis and research. Routledge: New York.

19. Holloway, I. (1997). Basic Concepts for Qualitative Research. Blackwell Science, London.

20. Hoyt, A. (1996). And then there were seven: Cooperative principles updated. Cooperative Grocer, January/ /February, pp. 1-6.

21. Jarosz, L. (2000). Understanding agri-food networks as social relations. Agriculture and Human Values, 17 (3), pp. 279-283.

22. Kloppenburg Jr. J., Lezberg, S., De Master, K., Stevenson, G.W., Hendrickson, J. (2000). Tasting food, tasting sustainability: Defining the attributes of an alternative food system with competent, ordinary people. Human Organization, Summer, pp. 177-186.

23. Lowe, P., Buller, H., Ward, N. (2001). Setting the next agenda? British and French approaches to the second pillar of the common agricultural policy. Journal of Rural Studies, 18 (1), pp. 1-17.

24. Maciejczak, M. (2009). Rolnictwo i obszary wiejskie źródłem dóbr publicznych - przegląd literatury. Zeszyty Naukowe SGGW Ekonomika i Organizacja Gospodarki Żywnościowej, 75, pp. 121-135.

25. Maciejczak, M. (2014). Process maturity of short food supply chains. Journal of Central European Green Innovation, 2 (4), pp. 87-102.

26. Maciejczak, M., Zakharov, K. (2011). Public goods as a source of rural development. In: Villányi, L., Káposzta, J., Nagy, H. (eds.) Development prospects of rural areas: Lagging behind in the CEE region. Szent István University, Gödöllö, pp. 253-266.

27. Mancino, L., Parliament, C. (2001). The city natural food co-ops: the role of customer preferences and characteristics when choosing among structural options. University of Minnesota, Minneapolis, MN.

28. Mikami, K. (2010). Capital procurement of a consumer cooperative: Role of the membership market. Economic Systems, 34 (2), pp. 123-132.

29. O'Sullivan, A., Sheffrin, S. (2003). Economics: Principles in Action. Prentice Hall, Needham, MA.

30. Sage, C. (2003). Social embeddedness and relations of regard: alternative 'good food' networks in south-west Ireland. Journal of Rural Studies, 19, pp. 47-60.

31. Seyfang, G. (2006). Ecological citizenship and sustainable consumption: Examining local organic food networks. Journal of Rural Studies, 22 (4), 383-395

32. Stephenson, T. (1963). Management in cooperative societies. Heinermann Publishing, London. 
Proceedings of the 2018 International Scientific Conference 'Economic Sciences for Agribusiness and Rural Economy' No 2, Warsaw, 7-8 June 2018, pp. 180-187

33. Streed, O., Cliquet, G., Kagan, A. (2017). Profiling the Natural Food Cooperative Members: Strategic Implications in Terms of Market Positioning and Governance. In: Hendrikse, G. (ed.) Management and Governance of Networks. Contributions to Management Science. Springer, pp. 111-130.

34. Sumner, J., McMurtry, J.J., Renglich, H. (2014). Leveraging the local: Cooperative food systems and the Local Organic Food Co-ops Network in Ontario, Canada. Journal of Agriculture, Food Systems, and Community Development, 4 (3), pp. 47-60.

35. Talonen, A., Jussila, I., Saarijarvi, H., Rintamaki, T. (2016). Consumer cooperatives: uncovering the value potential of customer ownership. Academy of Marketing Science Review, 6 (3), pp. 142-156.

36. Thompson, D. (1994). Co-operative principles then and now. Co-operative Grocer Magazine 53.

37. Vargo, S., Lusch, R. (2008). Service-dominant logic: Continuing the evolution. Academy of Marketing Science Review, 36 (2), pp. 1-10.

38. Williams, R. (2012). The Cooperative Movement: Globalization from Below. Ashgate Publishing, Farnham.

39. Zakharov, K., Maciejczak, M. (2018). Consumer Food Cooperatives As Complex Adaptive Networks - The Case of Five Cooperatives From Poland. Roczniki Naukowe SERiA, 20 (3), pp. 184-189. 